\title{
Gingival margin alterations and the pre-orthodontic treatment amount of keratinized gingiva
}

\author{
Alterações da margem gengival e a quantidade \\ de gengiva ceratinizada pré-tratamento \\ ortodôntico
}

\section{Luciane Quadrado Closs ${ }^{(a)}$ Paula Branco(b) \\ Susana Deon Rizzatto(c) \\ Dirceu Barnabé Raveli(d) \\ Cassiano Kuchenbecker Rösing(e)}

(a) PhD Student; (d) Chair - Department of Orthodontics, School of Dentistry of Araraquara, State University of São Paulo.

(b) MSc in Periodontology; (e) Professor of Periodontology - Lutheran University of Brazil.

(c) MSc in Orthodontics, Pontifical Catholic University of Rio Grande do Sul.

\author{
Corresponding author: \\ Luciane Quadrado Closs \\ R. Gen. Couto de Magalhães, 1070/801 \\ Porto Alegre - RS - Brazil \\ CEP: 90550-130 \\ E-mail: lucloss@uol.com.br
}

Received for publication on Oct 20, 2005 Sent for alterations on Mar 27, 2006 Accepted for publication on Sep 12, 2006

\begin{abstract}
The purpose of this retrospective study was to associate the amount of keratinized gingiva present in adolescents prior to orthodontic treatment to the development of gingival recessions after the end of treatment. The sample consisted of the intra-oral photographs and orthodontic study models from 209 Caucasian patients with a mean age of $11.20 \pm 1.83$ years on their initial records and $14.7 \pm 1.8$ years on their final records. Patients were either Angle Class I or II and were submitted to non-extraction orthodontic treatment. Gingival recession was evaluated by visual inspection of the lower incisors and canines as seen in the initial and final study models and intra-oral photographs. The amount of recession was quantified using a digital caliper and the observed post-treatment gingival margin alterations were classified as unaltered, coronal migration of the gingival margin or apical migration of the gingival margin. The width of the keratinized gingiva was measured from the mucogingival line to the gingival margin on the pre-treatment photographs. The teeth that developed gingival recession and those that did not have their gingival margin position changed did not differ in relation to the initial amount of keratinized gingiva $(3.00 \pm 0.61$ and $3.5 \pm 0.86 \mathrm{~mm}$, respectively). Paradoxically, teeth that presented a coronal migration of the gingival margin had a smaller initial amount of keratinized gingiva $(2.26 \pm 0.31 \mathrm{~mm})$. The mean amount of initial keratinized gingiva did not predispose lower incisors and canines to gingival recession.
\end{abstract}

Descriptors: Orthodontics; Gingival recession; Gingiva.

Resumo: O objetivo deste estudo retrospectivo foi associar a quantidade de gengiva ceratinizada existente em adolescentes pré-tratamento ortodôntico e o desenvolvimento de recessões gengivais pós-tratamento ortodôntico. A amostra consistiu de fotografias intra-orais e modelos de estudo de 209 pacientes leucodermas com idades médias de $11,20 \pm 1,83$ anos nos exames iniciais e 14,7 $\pm 1,8$ anos nos exames finais. Os pacientes eram Classe I ou II de Angle e foram submetidos a tratamento ortodôntico sem extrações. As recessões gengivais foram avaliadas por inspeção visual dos incisivos e caninos inferiores nas fotografias e nos modelos de estudo iniciais e finais dos pacientes. As alterações da margem gengival pós-tratamento foram medidas com paquímetro digital e subdivididas em inalterada, migração coronal da margem gengival, ou migração apical da margem gengival. A quantidade de gengiva ceratinizada foi medida da linha mucogengival à margem gengival nas fotografias pré-tratamento ortodôntico. Tanto os dentes que desenvolveram recessões gengivais como aqueles que não tiveram a posição da margem gengival alterada não diferiram entre si quanto à quantidade de gengiva ceratinizada inicial $(3,00 \pm 0,61$ e 3,5 $\pm 0,86 \mathrm{~mm}$, respectivamente). Contraditoriamente, dentes que apresentaram migração coronal da gengiva tinham uma quantidade menor de gengiva ceratinizada inicial $(2,26 \pm 0,31 \mathrm{~mm})$. A quantidade média de gengiva ceratinizada inicial não predispôs a recessões gengivais de incisivos e caninos inferiores.

Descritores: Ortodontia; Retração gengival; Gengiva. 


\section{Introduction}

The need for a supposedly adequate zone of keratinized gingiva before tooth movement is a controversal subject in the orthodontic and periodontic literature. ${ }^{10,14,30}$ It has been suggested that a certain ammount of attached gingiva is necessary for the maintenance of the integrity of the dento-gingival junction. The amount of attached gingiva - if any - required to minimize the occurrence or progression of gingival recessions, however, has never been established. ${ }^{11,24}$

The observations of Lang, Lö ${ }^{16}$ (1972) suggest that at least $2 \mathrm{~mm}$ of keratinized gingiva, corresponding to approximately $1 \mathrm{~mm}$ of attached gingiva, is recommended in order to maintain gingival health. This affirmation has been questioned in more recent studies. ${ }^{8,10,30}$ According to these studies, less than $1 \mathrm{~mm}$ of keratinized/attached gingiva may also be compatible with gingival health. Coatoam et al..$^{7}$ (1981) found that teeth with minimal widths of keratinized gingiva (less than $2 \mathrm{~mm}$ ) could withstand orthodontic forces.

Some authors recommend mucogingival surgery, as a preventive measure to avoid the development or progression of gingival recession in cases that have a thin keratinized gingiva. ${ }^{13,17}$ However, some reports emphasize that the absence of keratinized gingiva alone is not an indication for a surgical procedure. ${ }^{11,14}$ Ngan et al. ${ }^{21}$ (1991) found that placing a free gingival graft prior to orthodontic treatment had no effect on the extent of the improvement of gingival architecture occurring during treatment.

Some cross sectional studies in children, adolescents and adults demonstrate that the width of keratinized gingiva increases with age. ${ }^{5,28}$ Different studies, on the other hand, did not observe any increase in the width of attached gingiva from the deciduous to the permanent dentitions. ${ }^{6,26}$ Bimstein, Eidelman ${ }^{5}$ (1988) found that the attached gingiva tends to be narrower in the permanent dentition when compared to the primary dentition.

The absence of keratinized gingiva alone is not an indication for a periodontal surgical procedure. However, if recession increases during orthodontic treatment, then a gingival graft may be indicated. Orthodontic therapy where excessive gingival recession is present may be the indicated treatment. ${ }^{20}$
In a 10-year longitudinal study of untreated mucogingival defects, it was concluded that in the absence of gingival inflammation, areas with small amounts of keratinized gingiva may remain stable over long periods of time. ${ }^{12}$

In another longitudinal study in children, Andlin-Sobocki ${ }^{2}$ (1993) found that the increase of gingival width was greatest for sites with the smallest baseline widths of attached gingiva, and smallest for sites with the greatest baseline width. The author also observed that when the teeth were moved lingually, the gingival width increased and the clinical crown height decreased. In teeth moving facially, the gingival width decreased, and the facial gingiva sometimes receded. ${ }^{3}$

In a study with a sample of completed orthodontic cases, it was found that $1.3 \%$ of the patients showed a decrease in the width of keratinized gingiva because of either minimal lingual or labial movement of the mandibular incisors, whereas $0.69 \%$ had an increase in keratinized gingival width subsequent to lingual positioning of the incisors. ${ }^{10}$

Other factors may contribute to the development of recessions: difficulty in plaque control due to fixed orthodontic accessories, coronally attached frena and muscle attachments, abnormal tooth position, placement of artificial crowns, transverse expansion, proclination of teeth, fenestration or bony dehiscence. . $^{15,17,19,29}$

Wennström ${ }^{30}$ (1990) stated that the thickness of the soft tissue is more important than its quality. Therefore tooth movement, especially in the labial-lingual direction, should be preceded by careful examination of the dimensions of the tissues covering the pressure side of the teeth to be moved.

The aim of the present retrospective study was to associate the amount of pre-orthodontic treatment keratinized gingiva to the development of gingival recessions in adolescents submitted to orthodontic therapy.

\section{Material and Methods Subjects}

The sample consisted of records containing intra-oral photographs and orthodontic study models 
from 209 Caucasian adolescents (118 female and 91 male) pre- and post-orthodontic treatment. The patients presented initial mean $\pm S D$ age values of $11.20 \pm 1.83$ years and final mean $\pm S D$ age values of $14.7 \pm 1.8$ years. The mean active treatment time was $1.99 \pm 0.89$ years. The patients were treated by two orthodontists with fixed standard edgewise and Roth prescription straight wire appliances. During orthodontic treatment, tipping and bodily movement, including torque, of lower incisors and canines were performed. The final records were taken 28 days or more after removal of the appliances.

\section{Inclusion criteria}

To be included in the study, patients were either Angle Class II or Class I with transverse or vertical problems, with spacing or crowding in the lower anterior teeth not exceeding $4 \mathrm{~mm}$. Treatment was performed without extractions. Patients needed to have all lower incisors totally erupted and with apparent periodontal health. The exclusion criteria were: missing or non-erupted lower anterior teeth, Angle Class III patients, preexisting systemic diseases or medication associated with gingival changes. All patients in the study received oral hygiene instructions right after placement of the orthodontic appliances and during orthodontic treatment, as necessary.

\section{Main outcome}

The dependent variable of this study was gingival recession, which was evaluated by visual inspection of the study models and intra-oral photographs of the initial and final records of the orthodontically treated patients. Gingival recession was recorded when the labial cementoenamel junction was exposed or the buccolingual margin was markedly below the marginal level of the adjacent teeth in all lower incisors and canines.

Gingival recession was measured in milimeters at the midbuccal aspect of each of the mandibular incisors and canines, as the distance between the gingival margin and the cementoenamel junction. The amount of recession was quantified to the nearest $0.1 \mathrm{~mm}$, using a digital caliper (Mitutoyo Digimatic ${ }^{\circledR}$, Mitutoyo Ltd., UK). Patients' photographs and models were evaluated before and after orthodontic treatment and, based on the gingival margin alterations observed, teeth were classified as having an unaltered gingival position, coronal migration of the gingival margin or apical migration of the gingival margin.

\section{Independent variable}

\section{Assessment of keratinized gingival width}

The width of the keratinized gingiva was measured from the mucogingival line to the most apical point of the gingival margin. All measurements were made at the midline of the buccal aspect of the tooth to the nearest $0.5 \mathrm{~mm}$ using a digital caliper (Mitutoyo Digimatic ${ }^{\circledR}$, Mitutoyo Ltd., UK).

\section{Error of the method}

The reproducibility of the measurements on the records was assessed by statistically analyzing the differences between double measurements repeated on 20 randomly selected study models and photographs with a one week interval.

Kappa statistics was used to evaluate intra-examiner agreement of the presence of gingival recession, and perfect reproducibility was obtained with kappa $=1$.

Paired $t$ test and Pearson's correlation coefficient were utilized for assessing the reproducibility of the amount of gingival recession and the width of keratinized gingiva, respectively. For gingival recessions, a $\mathrm{p}=0.505$ and $\mathrm{r}=0.993$ were obtained, and for the width of keratinized gingiva, $\mathrm{p}=0.128$ and $r=0.922$ were achieved. The paired measurement differences never exceeded $0.3 \mathrm{~mm}$.

The amount of gingival recession and the width of keratinized gingiva were measured in photographs that did not represent the actual size of the variables measured. Thus, after the collection of the data, a multiplication factor was established to calculate the actual amount of gingival recession and width of keratinized gingiva. The enlargement correction for the photograph analysis was achieved by comparing the crown width of the upper right central incisor on the photo with the dimensions of the same tooth as recorded on the cast. As described by Djeu et al. ${ }^{9}$ (2002) the following equations were then used: 
Actual recession $=($ photographic measured recession $\times$ actual cast crown length) / photographic measured crown length

Actual width of keratinized gingiva $=$ (photographic width of keratinized gingiva $\times$ actual cast crown length) / photographic measured crown length

\section{Statistical analysis}

Data were analyzed using the SPSS (Statistical Package for Social Sciences, Inc., Chicago, Ill, USA). Tooth level analyses were performed. Differences between gingival margin alterations were tested by One-way Analysis of Variance, complemented by Tukey Multiple comparison test. Statistically significant differences were considered when $\mathrm{p}<0.05$.

\section{Results}

The initial amount of keratinized gingiva on the sites where a coronal gingival margin migration was detected were statistically smaller than in the cases that had an unaltered gingival position or apical gingival migration. The teeth that developed gingival recession and those that did not have their gingival margin position changed did not differ in relation to the initial amount of keratinized gingiva. (Table 1)

In Table 2, a summary of the Analysis of Variance of the data shown in Table 1 is presented. It can be observed that a statistically significant difference could be detected, confirming that the mean amount of keratinized gingiva pre-orthodontic treatment in the group where the gingival position presented coronal migration was smaller than in the groups where the gingival position was either unaltered or presented recession.

Table 1 - Initial amount (mm) of keratinized gingiva and gingival margin position - Tooth level analysis.

\begin{tabular}{l|c|c}
\hline \multirow{2}{*}{\multicolumn{1}{c}{ Classification }} & \multicolumn{2}{|c}{ Initial amount of keratinized gingiva } \\
\cline { 2 - 3 } & Mean & SD \\
\hline Coronal gingival migration & $2.26 \mathrm{~A}$ & 0.31 \\
\hline Unaltered gingival position & $3.50 \mathrm{~B}$ & 0.86 \\
\hline Apical gingival migration & $3.00 \mathrm{~B}$ & 0.61 \\
\hline
\end{tabular}

Means followed by distinct characters (A or B) are statistically different according to the Analysis of Variance complemented by Tukey Multiple comparison test at a .05 level of confidence.

\section{Discussion}

The present retrospective study assessed the amount of keratinized gingiva pre-orthodontic treatment as related to gingival margin alterations. In a previous study, the width of keratinized gingiva was measured in patients before orthodontic therapy and ranged from 0 to $8.0 \mathrm{~mm}$; after orthodontic treatment, it ranged from 0 to $7.7 \mathrm{~mm}$. $^{7}$

It has been demonstrated that, although the attached gingiva tends to increase post-eruption, the width of the keratinized gingiva remains relatively stable after the time the tooth breaks through the mucosa. ${ }^{25,26}$

Rose, App ${ }^{22}$ (1973) stated that, as the child progresses from the deciduous to the permanent dentition, there is an increase in the mean width of attached gingiva. If these earlier findings were absolute, the problem of a so called inadequate attached gingiva would hardly ever occur in adults. However, these studies were conducted in patients at various ages and did not have a longitudinal design. Part of the difficulties involved in such studies is the manner of assessing gingival width as well as recession. A few studies have reported reproducibility for the width of the keratinized gingiva, but all have used different methods of describing it: Artun, Krogstad ${ }^{4}$ (1987) give a Dahlberg error of $0.11 \mathrm{~mm}$ for intra-examiner agreement, with no discrepancy between recordings greater than $1 \mathrm{~mm}$; Andlin-Sobocki ${ }^{2}$ (1993) showed kappa statistics of 0.62 and 0.55 for inter-examiner agreement, and Andlin-Sobocki, Bodin ${ }^{3}$ (1993) found a total agreement in $80 \%$ of the double measurements, with $95 \%$ within $0.5 \mathrm{~mm}$ and all within $1 \mathrm{~mm}$. Based on the results described above, the results from gingival recession studies should be seen with caution due to some measurement errors involved. ${ }^{17}$

Table 2 - Analysis of Variance, complemented by Tukey test, concerning the classification of the gingival margin alterations and the pre-treatment amount of keratinized gingiva.

\begin{tabular}{l|c|r|c|c}
\hline Variation cause & $\begin{array}{c}\text { Degrees of } \\
\text { freedom }\end{array}$ & $\begin{array}{r}\text { Sum of } \\
\text { squares }\end{array}$ & $F$ & $p$ \\
\hline Classification & 2 & 6.34 & 4.43 & 0.012 \\
\hline Experimental error & 1,071 & 766.15 & & \\
\hline Total & 1,073 & 772.49 & & \\
\hline
\end{tabular}


The majority of studies that evaluated gingival recession have used the clinical crown length in the models to access the amount of gingival recession. ${ }^{4,9,23}$ In this study, since the clinical crown length might have been changed during the period of treatment, the measurements were performed directly on the gingival margin in the photographs, as described by Allais and Melsen.,18 Moreover, the reproducibility of our measurements was reported and considered adequate.

Some studies demonstrate that individual behavioral factors such as oral hygiene control and gingival biotype, among others, may contribute or predispose to gingival recession. ${ }^{18,30}$ Since this is a retrospective study, these variables could not be controlled. Measurements of Plaque Index, Probing Depth, Buccolingual amount of gingival tissue and type of orthodontic movement were not assessed in the present study due to the characteristics of the sample studied. Oral hygiene instructions were given as necessary and the included patients presented apparent gingival health.

The validity of using orthodontic records for measuring attached gingiva has been questioned. ${ }^{9}$ Trentini et al. ${ }^{27}$ (1995) demonstrated the validity of using photographs and study casts to accurately measure the width of keratinized tissue.

According to Coatoam et al. ${ }^{7}$ (1981), the greatest loss in width of keratinized gingiva following orthodontic treatment occurred in lateral incisors. It was suggested in a former study that teeth that are lingually displaced often had the greatest width of keratinized gingiva and, once the tooth is brought into proper alignment with orthodontic therapy, the result is a decrease in this width. ${ }^{22}$

\section{References}

1. Allais D, Melsen B. Does labial movement of lower incisors influence the level of the gingival margin? A case-control study of adult orthodontic patients. Eur J Orthod. 2003;25(4):343-52.

2. Andlin-Sobocki A. Changes of facial gingival dimensions in children: A 2-year longitudinal study. J Clin Periodontol. 1993;20(3):212-8.

3. Andlin-Sobocki A, Bodin L. Dimensional alterations of the gingiva related to changes of facial/lingual tooth position in
No reference was made to the specific tooth movement that was performed throughout the orthodontic period of treatment of the subjects in this study. However, in a recent study with an adult sample, the direction of tooth movement was not statistically related to the development or aggravation of gingival recession. ${ }^{1}$

The results of the present study are surprising in view of the established paradigm according to which the smaller the keratinized gingival dimensions, the more prompt teeth would be to gingival recessions. However, it should be taken into consideration that teeth that are orthodontically moved might be in a final position which allows a different gingival architecture. A normal amount of keratinized gingiva cannot be established, since this varies intra- and inter-individually. Understanding these findings is a challenge, but one could suppose that tooth movement could even permit a better gingival margin position, thus contradicting the need for pre-treatment gingival augmentation. Plaque accumulation and gingivitis, extrusive movements as well as buccolingual gingival dimensions could also account for these changes.

It should also be considered that orthodontic realignment might be an interesting factor related to gingival margin position.

\section{Conclusions}

In summary, considering its strengths and limitations, the findings of this study may lead to the conclusion that the mean amount of keratinized gingiva did not predispose lower incisors and canines to gingival recession.

permanent anterior teeth of children. A 2-year longitudinal study. J Clin Periodontol. 1993;20(3):219-24.

4. Artun J, Krogstad O. Periodontal status of mandibular incisors following excessive proclination. A study in adults with surgically treated mandibular prognathism. Am J Orthod Dentofacial Orthop. 1987;91(3):225-32.

5. Bimstein E, Eidelman E. Morphological changes in the attached and keratinized gingiva and gingival sulcus in the 
mixed dentition period. A 5-year longitudinal study. J Clin Periodontol. 1988;15(3):175-9.

6. Bosnjak A, Jorgic-Srdjak K, Maricevic T, Plancak D. The width of clinically-defined keratinized gingiva in the mixed dentition. ASDC J Dent Child. 2002;69(3):266-70.

7. Coatoam GW, Behrents RG, Bissada NF. The width of keratinized gingiva during orthodontic treatment: its significance and impact on periodontal status. J Periodontol. 1981;52(6):30713.

8. de Trey E, Bernimoulin JP. Influence of free gingival grafts on the health of the marginal gingiva. J Clin Periodontol. 1980;7(5):381-93.

9. Djeu G, Hayes C, Zawaideh S. Correlation between mandibular central incisor proclination and gingival recession during fixed appliance therapy. Angle Orthod. 2002;72(3):238-45.

10. Dorfman HS. Mucogingival changes resulting from mandibular incisor tooth movement. Am J Orthod. 1978;74(3):28697.

11. Farnaoush A, Schonfeld SE. Rationale for mucogingival surgery: a critique and update. J West Soc Periodontol Periodontal Abstr. 1983;31(4):125-30.

12. Freedman LA, Salkin LM, Stein MD. A 10-year longitudinal study of untreated mucogingival defects. J Periodontol. 1992;63(2):71-2.

13. Holmes HD, Tennant M, Goonewardene MS. Augmentation of faciolingual gingival dimensions with free connective tissue grafts before labial orthodontic tooth movement: an experimental study with a canine model. Am J Orthod Dentofacial Orthop. 2005;127(5):562-72.

14. Kennedy JE, Bird WC, Palcanis KG, Dorfman HS. A longitudinal evaluation of varying widths of attached gingiva. J Clin Periodontol. 1985;12(8):667-75.

15. Koke U, Sander C, Heinecke A, Muller HP. A possible influence of gingival dimensions on attachment loss and gingival recession following placement of artificial crowns. Int J Periodontics Restorative Dent. 2003;23(5):439-45.

16. Lang NP, Löe H. The relationship between the width of keratinized gingiva and gingival health. J Periodontol. 1972; 43(10):623-7.

17. McComb JL. Orthodontic treatment and isolated gingival recession: a review. Br J Orthod. 1994;21(2):151-9.
18. Melsen B, Allais D. Factors of importance for the development of dehiscences during labial movement of mandibular incisors: A retrospective study of adult orthodontic patients. Am J Orthod Dentofacial Orthop. 2005;127(5):552-61.

19. Moriarty JD. Mucogingival Considerations for the Orthodontic Patient. Curr Opin Periodontol. 1996;3:97-102.

20. Newman GV, Goldman MJ, Newman RA. Mucogingival orthodontic and periodontal problems. Am J Orthod Dentofacial Orthop. 1994;105(4):321-7.

21. Ngan PW, Burch JG, Wei SHY. Grafted and ungrafted labial gingival recession in pediatric orthodontic patients: effects of retraction and inflammation. Quintessence Int. 1991;22(2):103-11.

22. Rose ST, App GR. A clinical study of the development of the attached gingiva along the facial aspects of the maxillary and mandibular anterior teeth in the deciduous, transitional and permanent dentitions. J Periodontol. 1973;44(3):131-9.

23. Ruf S, Hansen K, Pancherz K. Does orthodontic proclination of lower incisors in children and adolescents cause gingival recession? Am J Orthod Dentofacial Orthop. 1998;114(1):100-6.

24. Schoo WH, Velden UVD. Marginal soft tissue recessions with and without attached gingiva. J Periodontal Res. 1985;20(2):209-11.

25. Smith RG. A longitudinal study into the depth of the clinical gingival sulcus of human canine teeth during and after eruption. J Periodontal Res. 1982;17(4):427-33.

26. Tenenbaum H, Tenenbaum M. A clinical study of the width of the attached gingiva in the deciduous, transitional and permanent dentitions. J Clin Periodontol. 1986;13(4):270-5.

27. Trentini CM, Moriarty JD, Phillips C, Tulloch JF. Evaluation of the use of orthodontic records to measure the width of keratinized tissue. J Periodontol. 1995;66(6):438-42.

28. Vincent JW, Machen J, Levin M. Assessment of attached gingiva using the tension test and clinical measurements. J Periodontol. 1976;47(7):412-4.

29. Wennström JL. Mucogingival considerations in orthodontic treatment. Semin Orthod. 1996;2(1):46-54.

30. Wennström JL. The significance of the width and thickness of the gingiva in orthodontic treatment. Dtsch Zahnarztl Z. 1990;45(3):136-41. 